\title{
Special issue: managing fragmentation and complexity in the emerging system of international climate finance
}

\author{
Jonathan Pickering ${ }^{1} \cdot$ Carola Betzold $^{2} \cdot$ Jakob Skovgaard $^{3}$
}

(C) The Author(s) 2017. This article is published with open access at Springerlink.com

\author{
Abbreviations \\ ADB Asian Development Bank \\ CDM Clean Development Mechanism \\ CBDR Common but differentiated responsibilities and respective capabilities \\ COP Conference of the Parties \\ GCF Green Climate Fund \\ GEF Global Environment Facility \\ ODA Official development assistance \\ OECD Organization for Economic Cooperation and Development \\ UNFCCC United Nations Framework Convention on Climate Change
}

Climate finance occupies the lion's share of funding under international environmental agreements (UNEP 2012: 467-469), and its volume is likely to increase substantially if current multilateral targets are fulfilled. At the landmark summit under the United Nations Framework Convention on Climate Change (UNFCCC) in Paris in 2015, countries recognized the "urgent need to enhance the provision of finance" to assist developing

Jakob Skovgaard

jakob.skovgaard@svet.lu.se

Jonathan Pickering

jonathan.pickering@canberra.edu.au

1 Centre for Deliberative Democracy and Global Governance, University of Canberra, Canberra, ACT, Australia

2 University of Antwerp, Antwerp, Belgium

3 Lund University, Lund, Sweden 
countries in addressing climate change (UNFCCC 2015: Decision 1/CP.21, Preamble). ${ }^{1}$ They also recalled 2009 commitment of developed countries to mobilize US \$100 billion annually by 2020 from public and private sources, and agreed to set a new, higher collective financing goal before 2025 (UNFCCC 2015: Decision 1/CP.21, paragraphs 114 and 53).

Climate finance has a vital role to play in enabling developing countries to mitigate climate change and adapt to its impacts. Climate finance may enhance both the effectiveness and the fairness of the global response to climate change, not least because adaptation finance can support the most vulnerable countries, while mitigation finance can assist developing countries to make the transition to low-carbon societies. However, efforts to translate multilateral goals into effective action face a number of challenges. Current levels of funding fall well short of existing targets, let alone developing countries' needs (see Sect. 1 below). Countries seeking support face numerous hurdles to accessing funding from a tangle of institutions charged with governing and delivering climate finance.

Climate finance is often seen as integral to the broader climate regime, not least because funding pledges by developed countries may encourage developing countries to boost their mitigation pledges, and thereby secure a wider bargain on climate change (Romani and Stern 2013: 117). Moreover, in a world where global climate governance is fragmented across many international and national institutions rather than strongly centralized at the multilateral level (Keohane and Victor 2011), it is unsurprising that institutional arrangements for climate finance are also fragmented (see Gomez-Echeverri 2013). Nevertheless, we cannot simply assume that the institutional dynamics of climate finance precisely reflect those of the overarching climate system or regime complex. As the articles in this volume attest, complexity and fragmentation take on specific contours in the context of climate finance, not least due to the way that institutions for climate finance interact with institutions for development finance. Consequently, it is worth exploring climate finance as a system or subsystem in its own right, including its defining characteristics, the causes of its evolution, and the effects it produces.

Against this backdrop, this special issue aims to provide insights on the dynamics of the climate finance system. The recent proliferation of institutions associated with climate finance calls for greater attention to the role that these institutions play as part of a broader, emerging system. We focus in particular on the role of complexity and fragmentation as both causes and consequences of the way that the climate finance system has evolved.

Systemic analysis of climate finance is relevant to broader theoretical engagement with issues including the role of financing in international environmental agreements (e.g. Keohane and Levy 1996), financing of global public goods (Kaul and Goulven 2003), and institutional complexity and fragmentation (Biermann et al. 2009; Keohane and Victor 2011). However, as we outline in Sect. 2 below, analysis of complexity and fragmentation remains more developed at the level of overarching institutional regimes or regime complexes than at the level of subsystems nested within those larger systems. More broadly, although climate finance has attracted increasing attention in scholarly literature, it remains under-researched and under-theorized, and stands in need of further integration of and dialogue between different approaches to the topic.

The articles in this special issue arose from a workshop on "Climate Finance: Taking Stock, Future Directions for Policy and Research" held at Lund University in April 2015,

\footnotetext{
${ }^{1}$ For the purposes of this introduction we define climate finance as financial flows to developing countries "whose expected effect is to reduce net greenhouse gas emissions and/or to enhance resilience to the impacts of climate variability and the projected climate change" (Gupta et al. 2014: 1238).
} 
which aimed to integrate different approaches to the study of climate finance and in this way generate coherent theoretical insights and practical recommendations for policy grounded in thorough empirical analysis.

\section{The emergence of climate finance in international negotiations and research}

Finance has been a central element of the climate change regime since its inception. The UNFCCC stipulates that, in accordance with the principle of "common but differentiated responsibilities and respective capabilities," developed countries shall "provide new and additional financial resources" to assist developing countries in fulfilling their obligations under the Convention (UNFCCC 1992: Articles 3(1), 4(2) and 4(3)). The UNFCCC also defines "a mechanism for the provision of financial resources" under the treaty's Conference of the Parties (COP) (UNFCCC 1992: Article 11). The Global Environment Facility (GEF) — established shortly before the 1992 Rio Summit where the Convention was adopted-served at first as the sole operating entity of the Convention's financial mechanism.

With the notable exception of the market-based Clean Development Mechanism (CDM) established under the Kyoto Protocol, only small amounts of public funding flowed to developing countries during the early years after the Convention entered into force (Michaelowa and Michaelowa 2011). From an early stage, developed countries drew on official development assistance (ODA) budgets to raise climate finance and often opted to channel funds through bilateral institutions rather than multilateral funds. Only in 2001 did countries agree on the need for further funding and institutional arrangements, establishing three new funds: the Least Developed Countries Fund and the Special Climate Change Fund under the Convention, and the Adaptation Fund under the Kyoto Protocol (UNFCCC 2001: Decisions 7/CP.7 and 10/CP.10). Capitalizing these funds, however, has been difficult from the start and climate finance only rose to the top of the agenda in more recent rounds of negotiations, starting with the Bali Action Plan in 2007. Although the 2009 Copenhagen Summit is often seen as a failure, the Copenhagen Accord's provisions on climate finance-notably the target of mobilizing jointly US $\$ 100$ billion a year by 2020 "from a wide variety of sources, public and private, bilateral and multilateral, including alternative sources of finance" (UNFCCC 2009: Decision 2/CP.15, paragraph 8) - are widely viewed as a breakthrough (Gomez-Echeverri 2013).

At COP 16 in Cancún in 2010, Parties established the Green Climate Fund (GCF; the second operating entity of the Convention's financial mechanism) with the expectation that a significant share of climate finance would be channeled through this new fund (UNFCCC 2010: Decision 1/CP.16, paragraphs 100 and 102). Despite recent pledges to the Fund and for climate finance more broadly, there is still an undisputed gap between available finance and the $\$ 100$ billion target for mobilizing public and private finance by 2020 (Nakhooda 2015). Estimates of current flows (of public as well as private finance) use widely varying definitions and thus generate divergent conclusions (UNFCCC Standing Committee on Finance 2014; see Roberts and Weikmans 2017). Concerns remain that some pledged funding has not reached its intended beneficiaries (UNFCCC Standing Committee on Finance 2014: 49) and is not clearly additional to existing aid flows or targets (Nakhooda et al. 2013: ii; see Sect. 3.1.2 below). 
In parallel with its ascent in the climate negotiations, climate finance has received more academic attention. ${ }^{2}$ A growing number of recent studies examine climate finance from a range of perspectives. Besides general assessments of overall financial flows (Buchner et al. 2014) and patterns of allocation (e.g. Abadie et al. 2013; Halimanjaya 2015), much research focuses on discrete institutions such as the Adaptation Fund (Persson and Remling 2014; Stadelmann et al. 2014) or the GCF (Abbott and Gartner 2011) or on specific funding sources (e.g. Hepburn and Müller 2010; Hourcade et al. 2012; Romani and Stern 2013; Aglietta et al. 2015). Relatively little research to date provides theoretical perspectives on the broader climate finance system, with the exception of several analyses on fairness and justice (e.g. Grasso 2010; Ciplet et al. 2013), accountability and power (Ballesteros et al. 2010), democracy (Schalatek 2012) and effectiveness (Ellis et al. 2013). Only a few joint scholarly publications on climate finance have appeared to date (Stewart et al. 2009; Michaelowa 2012; Haites 2011; 2013). While they provide valuable insights, none of these analyzes climate finance from a systemic or integrated theoretical perspective.

\section{A systemic perspective on climate finance}

We define a system as "a set of things...interconnected in such a way that [they] produce their own pattern of behavior over time" (Meadows 2008: 2). Scholars have recognized for some time that global environmental governance has become a system that is more than the sum of individual treaties (Najam et al. 2004). Before evaluating the character of climate finance governance as a system, it is necessary to argue why we think it is useful to start from the characterization of climate finance governance as a "system," 3 and explore the added value and limitations of this characterization.

One potential objection is that climate finance governance is just one component of a broader system of governance, namely the global climate regime, of which the UNFCCC is a major but not exclusive component. However, given the increasing institutional complexity of climate finance governance, it is now important to consider to which degree climate finance governance operates in a way that is "systemic" in its own right and in ways that are distinct from the broader system of climate governance. Importantly, while the climate governance system is often described as a regime complex (Keohane and Victor 2011) with different regimes as components, we focus on a system (or subsystem) within the climate governance system which is defined not in terms of being a distinct regime or institution, but in terms of the subject addressed, i.e., climate finance. In fact, the climate finance system criss-crosses several regimes.

A second objection is that climate finance is characterized by poor accountability and weak governance mechanisms to a degree where it does not make sense to talk about a functioning system for governing climate finance (see Roberts and Weikmans 2017). Here, it is important to distinguish the question of whether a system is dysfunctional from the question of whether it is a system at all. Institutions-ranging from global financial markets to development assistance and the global arms trade-may interact in systemic ways even if they do so in ways that are moderately or deeply dysfunctional.

\footnotetext{
${ }^{2}$ For an early analysis of the GEF see Keohane and Levy (1996).

${ }^{3}$ While we focus on the governance aspects of climate finance (rather than, say, its technological aspects) and thus on what could be called the "climate finance governance system", we refer to the system briefly as the "climate finance system".
} 
As we argue that climate finance constitutes a system of sorts, this raises questions regarding what kind of system it is, why it has evolved the way it has, and what effects the system produces. These questions speak to a broader programme of research in international relations concerning the characterization, causes and consequences of complex governance systems. This research has been framed in a number of different ways, ranging from governance architectures (Biermann 2014) to regime complexes (Raustiala and Victor 2004) and complex adaptive systems (Kim and Mackey 2014). For present purposes, we need not privilege one conceptual framework over another but note their common interest in systemic behavior. Within these bodies of literature, a number of concepts have emerged that are important for evaluating systemic characteristics. At the international level, the idea of "fragmentation" captures the idea of

a patchwork of international institutions that are different in their character (organizations, regimes, and implicit norms), their constituencies (public and private), their spatial scope (from bilateral to global), and their subject matter (from specific policy fields to universal concerns) (Biermann et al. 2009: 16; see also Zelli and van Asselt 2013; van Asselt 2014).

Relatedly, research on "polycentric" modes of governance (Ostrom 2010; Jordan et al. 2015) spans both the international and domestic levels in terms of studying the causes and consequences of governance without a single, hierarchical center of authority.

In subsequent sections, we build on theories of fragmentation and complexity to explore how articles in the special issue help to address outstanding questions in this area of the literature. In doing so, we show how the case of climate finance helps to address broader questions in research on international environmental agreements such as: What international and domestic factors influence the evolution of international environmental regimes? Is international regime complexity or fragmentation beneficial or detrimental to global environmental governance? And how can regime complexity be managed to achieve better outcomes?

\section{Analyzing fragmentation and complexity in climate finance governance}

Applying to climate finance a typology employed by Zelli and van Asselt (2013: 9) for evaluating fragmentation, we seek to understand (1) how we can describe and map this fragmented and complex climate finance system; (2) the underlying causes of its fragmentation and complexity; (3) the consequences of fragmentation and complexity for the system, as well as (4) how policy responses can improve the system or its components. As outlined below, we also seek to expand the conceptual framework for fragmentation to enable closer exploration of the relationship between international fragmentation and domestic politics.

\subsection{Mapping}

Mapping the climate finance system involves two key aspects: (1) delineating the scope and boundaries of the system, including its relation to other systems; and (2) assessing the degree of fragmentation or complexity across the system and its components. 


\subsubsection{The scope of the system}

Delineating the boundaries of the climate finance system is challenging, not least because of its interactions with other systems, the broader system for climate change governance (e.g. issues such as technology transfer and capacity building) as well as related systems, particularly development assistance. In addition, climate finance flowing from multilateral commitments forms part of a broader "landscape" of international and domestic private investment in clean technologies and adaptation to climate change (Buchner et al. 2014). In this sense, we may speak of a narrow understanding of the climate finance system-one bounded primarily by the finance that counts as having been mobilized by parties to the UNFCCC - and a broader understanding that encompasses all global investment to address climate change. Most contributions to this special issue focus primarily on the narrower understanding of climate finance, while some also look to the broader understanding (see Delina 2017; Pauw 2017). Importantly, the line between the narrower and broader understandings of the system is often hard to ascertain due to difficulties in assessing which flows of private investment have been mobilized by developed country governments (and therefore should count toward multilateral targets) and which flows would have occurred regardless (Pauw et al. 2016).

\subsubsection{Fragmentation across the system and over time}

For the purpose of categorizing the components of the system and their interrelations, the dimensions across which fragmentation may occur (as outlined in Biermann et al. 2009 above) provide a useful starting point: institutions, actor constellations and norms. We may then apply this set of categories to specific components or functions of the climate finance system: generating resources, allocating and delivering resources, and overall governance and oversight (Parker et al. 2009).

Regarding institutional fragmentation, one of the least controversial statements that could be made about current arrangements for governing international climate finance is that they are significantly fragmented (Pickering et al. 2015a; Gomez-Echeverri 2013: 641). Importantly, not only have a range of new institutions emerged with a specific mandate to govern or deliver climate finance, but existing institutions-notably from the development assistance system-are also an important (albeit contested) conduit for climate finance. The development assistance system has long been significantly fragmented (Greene 2004), and to the extent that the two systems overlap, they may share a degree of fragmentation. The climate finance governance system now includes multilateral funds such as the GCF (in addition to the GEF), multilateral development banks, bilateral aid agencies and funds in contributor countries, national climate change trust funds in recipient countries, and new multilateral monitoring bodies such as the UNFCCC's Standing Committee on Finance. This proliferation reflects countries' expectations that the 2020 commitment would be fulfilled from a range of sources, both public and private, and would be distributed through different channels, both multilateral and bilateral (UNFCCC 2009: Decision 2/CP.15, paragraph 8).

In terms of fragmentation of actor constellations, these institutions often differ in their membership, most evidently when one compares bilateral and multilateral institutions. Yet, the multilateral institutions involved with climate finance also differ in membership, as some have universal membership (especially the UN institutions) while others are restricted to industrialized countries (e.g. the OECD) or specific regions (the regional 
development banks). The involvement of private actors in climate finance adds further complexity to the system (Stadelmann et al. 2013; see also Pauw 2017).

Finally, concerning norm fragmentation, the climate finance institutions embody and promote different norms to varying degrees. Equity-oriented norms such as historical responsibility and "common but differentiated responsibilities and respective capabilities" (CBDR) (UNFCCC 1992: Article 3(1); see Skovgaard 2017) are often promoted by developing countries, while norms of efficiency and effectiveness are more popular among industrialized countries (Stadelmann et al. 2014; Pittel and Rübbelke 2013). CBDR implies that the burdens or efforts associated with addressing climate change (including for mitigation and climate finance) should be distributed according to countries' responsibility and capacity, often measured, respectively, in terms of contribution to greenhouse gas emissions and level of income (see Dellink et al. 2009; Pickering et al. 2015a). Other foundational norms of climate finance-particularly the principle that climate finance should be "new and additional" - have also been the subject of intense contestation among developed and developing countries. The principle of additionality was included in the Convention (UNFCCC 1992: Article 4(3)) due to the concerns of developing countries that developed countries would divert funds for climate finance from existing flows of development finance. Yet there is no agreed upon baseline against which additionality can be measured (Stadelmann et al. 2011).

At the same time, the climate finance system has generated some measures to reduce or at least manage fragmentation, including: the creation of the GCF as the flagship multilateral climate fund; the creation of the Standing Committee on Finance (which advises the UNFCCC's Conference of the Parties on how to improve the coherence and coordination of climate finance); standardized UNFCCC requirements for reporting on climate finance; and the OECD's introduction of a common set of markers (the "Rio markers") among contributor countries for tracking climate-related development assistance.

\subsubsection{Contributions of the special issue: mapping}

Most literature on fragmentation focuses on what might be called the "horizontal" dimension, namely fragmentation across international institutions (e.g. Zelli 2011). Yet it is also instructive to focus on the "vertical" dimension of fragmentation; that is, on the extent to which actor constellations, norms and institutions involved in climate finance are fragmented across national and subnational levels of governance, rather than purely on the international ("horizontal") level. ${ }^{4}$ In particular, the special issue highlights the role of political dynamics within individual countries (see for example Skovgaard 2017; Pickering and Mitchell 2017; Pickering et al. 2015b).

All contributions in this special issue highlight its fragmented nature and the multiplicity of partly overlapping institutions, interests and mandates. Thus, it comes as no surprise that there are norm conflicts, for instance between developing and developed countries on the role of private finance (Pauw 2017), among finance ministries on the rationales for climate finance (Skovgaard 2017), or among political parties on the level of climate finance that contributor countries should provide (Pickering and Mitchell 2017). Yet the articles also find some evidence for synergies and shared norms. While developing

\footnotetext{
4 Similarly, Morin and Orsini (2013) have developed a theoretical framework for studying the interaction between institutional complexity or fragmentation at the international level and domestic "policy coherence" (see also Bernstein and Cashore 2012). The idea of polycentric governance also encompasses vertical as well as horizontal dimensions (Ostrom 2010).
} 
and developed countries differ regarding the role for private climate finance in meeting global financing targets, they seem agree on the vital role of the private sector in implementing adaptation measures at the local level (Pauw 2017). Meanwhile, Betzold and Weiler (2017) find that allocation patterns reflect to some extent broad agreement among countries about the importance of vulnerability in distributing adaptation finance.

\subsection{Causes}

\subsubsection{Key concerns}

Why is the climate finance system as fragmented and complex as it is? To some extent, fragmentation and complexity are common features not only of the broader climate system but also of international institutional arrangements more generally, not least because of the challenges of achieving cooperation among countries with diverse interests (Keohane and Victor 2011) and the need for an institutional division of labor in governing complex global problems (Zürn and Faude 2013). In addition, contemporary institutional innovations at the international level typically do not take place in an institutional vacuum but against the backdrop of a web of arrangements for governing related areas and are thus shaped by institutional path dependencies (Raustiala and Victor 2004: 279). To some extent, then, new arrangements inherit a degree of fragmentation and complexity from preexisting arrangements inherited from the climate governance system or from other systems (e.g. development assistance; see Zelli and van Asselt 2013).

However, since degrees of fragmentation may vary between different components of a regime, the question arises as to whether this is due to the overall problem structure of global climate policy, the structure of specific problems within the regime, or other factors. Thus, for example, most analyses of climate finance from a public goods perspective argue that whereas mitigation constitutes a global public good, adaptation constitutes a local or regional public or a private good (Paavola and Adger 2006; Rübbelke 2011; for an exception, see Khan and Roberts 2013). This distinction has been employed to explain the relative under-funding of adaptation compared to mitigation (Abadie et al. 2013) but could also have implications for fragmentation. In this respect, the degree of fragmentation may be influenced not only by the underlying nature of the problem but also by actors' perceptions of its nature.

\subsubsection{Contributions of the special issue: causes}

Some articles explore the ways in which divergent interests and norms as well as epistemic uncertainty-about the impacts of climate change and the appropriate responses to those impacts - can foster fragmentation (Hall 2017; Roberts and Weikmans 2017; Betzold and Weiler 2017). A further question concerns how domestic fragmentation-for example, in the form of norm contestation among or within bureaucratic agencies or political partiesinfluences and drives international fragmentation (Skovgaard 2017; Pickering and Mitchell 2017).

All contributions, in one way or another, point to the lack of clear, agreed multilateral definitions and standards. What are adaptation and adaptation finance (Hall 2017; Pauw 2017)? How is development different from adaptation or mitigation (Delina 2017; Hall 2017)? This ambiguity partly reflects the different interpretations of these concepts resulting from uncertainty about the nature of the task at hand (what Hall terms "epistemic ambiguity"), but is also partly a result of heterogeneous preferences or "strategic 
ambiguity," or deliberately vague wording in international agreements that gives actors discretion to pursue their own interests. Convergence and divergence of preferences across similar ministries (in this case finance ministries) from different countries may increase as well as reduce fragmentation (Skovgaard 2017). Political polarization within contributor countries may increase fragmentation by undermining the predictability of financing flows and eroding support for multilateral funding channels (Pickering and Mitchell 2017).

Conversely, some papers highlight possible causes of reduced fragmentation. Thus, international pressure from contributor and recipient countries may reduce fluctuations in support within countries where climate change remains politically polarized (Pickering and Mitchell 2017).

\subsection{Consequences}

\subsubsection{Key concerns}

The consequences of fragmentation and complexity may be understood in a descriptive or an evaluative sense. From a descriptive standpoint, what are the implications of fragmentation and complexity for the outputs and outcomes of emerging climate finance system, including negotiation dynamics and flexibility? In relation to domestic-international dynamics, how does international fragmentation-for example, the absence of multilaterally agreed norms on how climate finance should be raised-in turn encourage and shape domestic fragmentation? From an evaluative standpoint, how can we assess the implications of fragmentation for values such as accountability, democratic legitimacy, effectiveness and equity?

Even when the overall phenomenon of fragmentation is defined in a value-neutral sense, particular types of fragmentation are often seen as having negative consequences for global climate governance (Biermann et al. 2009: 31). In the context of climate finance, norm conflicts could undermine the equitable allocation of funding, while multiple institutional arrangements could impede effectiveness, not least by imposing administrative burdens on recipient countries seeking to access funds (Gomez-Echeverri 2013: 641) requiring, for example, compliance with different social and fiduciary safeguards. Channeling funding through a wide variety of institutions with different accounting standards and decisionmaking arrangements could also impede transparency and accountability, and favor incumbent institutions (such as national aid agencies) in which developed countries have greater influence (Schalatek 2012).

Others view fragmentation in global climate governance more positively (e.g. Keohane and Victor 2011; Ostrom 2010; Rayner 2010). A fragmented climate finance system may offer some benefits, including speed, flexibility and innovation. For example, using established institutions (such as bilateral or multilateral funds) could increase the speed of finance delivery, particularly during periods while climate-specific multilateral funds such as the GCF are under construction. Gomez-Echeverri argues that "the multiplicity of actors has made it easier to find a match between the need for finance and potential suppliers" (Gomez-Echeverri 2013: 641). A degree of redundancy or duplication may also help the system to cope with external shocks (Kim and Mackey 2014). Some commentators also argue that multiplicity can encourage experimentation and learning (Hoffmann 2011), e.g. because initiatives that are not possible within the consensus-based UNFCCC may be possible in other institutions where smaller groups of like-minded actors can launch cooperative ventures. The greater participation of non-state actors in climate finance could help to improve the democratic legitimacy of climate finance (Schalatek 2012), but doing 
so may require a relatively higher degree of vertical fragmentation or decentralization in governance arrangements.

\subsubsection{Contributions of the special issue: consequences}

Perhaps the most immediate consequence of fragmentation and complexity associated with ambiguous definitions is the problems that arise in monitoring whether wealthy countries' funding pledges have been fulfilled. A web of different institutions with different accounting standards makes it difficult to track and hold to account actors involved in raising or managing climate finance (see Delina 2017; Hall 2017; Roberts and Weikmans 2017). Furthermore, climate finance flows-however defined and measured — are subject to volatility arising from domestic political factors due to the large measure of discretion according to wealthy countries in how they fulfill their pledges (Pickering and Mitchell 2017). This lack of predictability tends to undermine trust in climate negotiations, which in turn impedes global progress on avoiding dangerous climate change.

Lack of agreed rules across institutions and actors may also impede effectiveness in generating or allocating resources (see Betzold and Weiler 2017; Hall 2017). For example, in the absence of shared commitments to phase out carbon-intensive investments, institutions within the development finance system may undermine their own climate finance objectives, for example by continuing to provide funding for fossil fuel power generation (Delina 2017). Similarly, contributor countries may not adhere to multilaterally agreed principles when allocating adaptation finance bilaterally (Betzold and Weiler 2017).

Despite these findings, the contributions do not view the fragmented nature of the climate finance system as entirely problematic: fragmentation and complexity may have some beneficial consequences. For example, the multiplicity of actors may be an opportunity to leverage funding from as many sources as possible, both multilateral and bilateral, public and private (Pauw 2017). Vague definitions of adaptation finance may also provide multilateral organizations with greater autonomy to develop contextual, practice-based understandings of what adaptation requires in different local circumstances, and arguably also enhance mainstreaming of adaptation into development finance (Hall 2017).

\subsection{Responses}

\subsubsection{Key concerns}

Given the uneven consequences of the fragmented system, how should policymakers and stakeholders respond? In other words, how can the system or its individual components be made more accountable, effective and equitable? As outlined in Sect. 3.1.2, parties to the UNFCCC have already taken some steps to reduce or manage fragmentation, but broader questions persist about next steps. Should policymakers and stakeholders seek to seek to limit the fragmentation of the system in order to improve it as a whole? Or should they instead focus on individual components of the system and how to make these as accountable and effective as possible, while taking the extent of overall fragmentation as given? And how important and politically feasible is it to arrive at agreed multilateral standards for accounting for financial flows and for defining key concepts such as climate finance and adaptation? 


\subsubsection{Contributions of the special issue: responses}

Given the recurring theme of ambiguity, it is not surprising that numerous contributions call for clearer definitions, agreed accounting standards and better oversight to make the climate finance system more accountable and effective (Betzold and Weiler 2017; Hall 2017; Pauw 2017; Roberts and Weikmans 2017). While the development of common standards is a high priority, in the interim individual actors can take steps to reduce norm conflicts within their own policies and practices. Thus, Delina (2017) argues that multilateral development banks such as the Asian Development Bank should scale back their investments in fossil fuels in order to minimize contradictions with their growing emphasis on financing sustainable energy.

To address adverse consequences of fragmentation generated by domestic political conflict, Pickering and Mitchell (2017) propose improved multilateral oversight of arrangements to share the global financing effort, including through structured replenishments of multilateral funds. They also argue that diversifying the sources of climate finance may help to reduce the unpredictability inherent in any single source of funding (e.g. aid budgets; see Pickering and Mitchell 2017), even if such a strategy may tend to increase rather than reduce institutional fragmentation. Skovgaard (2017) finds that strengthening forums for finance ministry representatives to cooperate on climate finance $c a n$ be a fruitful venue for reducing promoting frame convergence between finance ministries and thus reduce norm fragmentation, although expanding such forums contributes to institutional fragmentation.

\section{Overview of the papers}

Three papers (Betzold and Weiler 2017; Hall 2017; Pauw 2017) specifically focus on adaptation finance. Contributor countries largely provide their adaptation finance through bilateral channels using funds drawn from official development assistance budgets. This preference potentially increases institutional fragmentation, yet Betzold and Weiler show that contributors overall provide relatively more adaptation aid to vulnerable developing countries, in line with collective promises made under the UNFCCC.

At the same time, what exactly counts as adaptation, and hence as adaptation finance, is not clearly defined. As Hall argues, this reflects epistemic ambiguity rather than strategic ambiguity alone: definitions are unclear not merely because of diverse interests, but because states are genuinely uncertain about the exact nature of the task of adaptation. As a result, international organizations responsible for implementing adaptation initiatives have considerable flexibility and autonomy, but at the same time, it is difficult to measure and track levels of multilateral adaptation finance.

Similar opportunities and problems affect private adaptation finance, as Pauw finds. While ambiguous definitions make it hard to monitor private adaptation finance, they allow for different interpretations and roles of the private sector at different levels. Accordingly, development institutions can closely collaborate with the private sector and thus achieve important co-benefits such as job creation and economic growth.

What counts as mitigation finance is somewhat clearer, although not uncontested. ${ }^{5}$ Delina examines how the Asian Development Bank (ADB) has become an actor in the

\footnotetext{
5 Some categories often classed as mitigation finance remain controversial, for example those that involve a reduction in emissions against a business-as-usual scenario but still rely on fossil fuels-such as efficiency improvements in coal-fired power plants-or other controversial technologies such as nuclear energy (King 2015).
} 
climate finance system by boosting its support for sustainable energy, yet ADB needs to find answers to a number of questions, such as how to scale back its ongoing support for fossil fuel investments and how to coordinate with other climate finance actors.

Two papers examine complexity and fragmentation in climate finance (spanning adaptation and mitigation) with a focus on national governments. Skovgaard explores the role of finance ministries in shaping national negotiating positions on climate finance through case studies of the Danish, Indian, Indonesian and US finance ministries. The paper underscores that the climate finance system differs from the overarching climate governance system in that the former involves finance ministries and the norms and frames employed by those ministries to a much larger degree than the latter. Skovgaard argues that finance ministries may frame climate finance either as expenditure to be limited or as an instrument for correcting the market failure of climate change. His paper shows that developing and industrialized countries subscribe to either frame and that the finance ministries that did not have the lead role within their national delegations in negotiations on climate finance (Indonesia, Denmark) were more oriented toward the "market failure" frame than those finance ministries that had the lead role (India, the US).

Pickering and Mitchell explore political determinants of national support for climate finance through a case study of Australia. Like several other major economies (notably the United States and Canada), Australia remains heavily dependent on fossil fuel production and exports, and public debate about climate change is highly polarized. Accordingly, Pickering and Mitchell find that changes of government affect the predictability of national support for climate finance. Nevertheless, they find that international pressure may encourage governments to contribute to collective efforts (such as raising resources for the GCF) even though they are not otherwise predisposed to take ambitious measures to address climate change.

The special issue concludes with a postface by Roberts and Weikmans, who address the overall theme of the special issue and argue that the lack of internationally agreed accounting rules for climate finance makes it impossible to determine whether industrialized countries' pledges have been met and where climate finance is or is not flowing. This lack of clarity in turn erodes trust in the climate change negotiations and creates serious problems of duplication and coordination. Only a set of clearly defined accounting rules ensuring transparency can solve these issues.

\section{Conclusion}

Overall, the contributions to the special issue underscore the fragmented quality of the climate finance system. As such, the contributions confirm earlier findings in this area (see Sect. 1) but on a more extensive and varied empirical basis within an integrated analytical framework. The contributions also support the claim that the question of fragmentation in climate finance cannot be reduced to the fragmentation of the overall climate governance system; particularly, the interaction with development finance adds a distinct dimension of complexity to climate finance. At the same time, the contributions help to expand the reach of fragmentation as an analytical framework in two directions: by assessing fragmentation in subsystems of climate governance and its relationship to these dynamics in other systems; and by exploring the "vertical" dimension of fragmentation in global governance through analysis of domestic politics. 
Future research can draw on these findings to conduct more in-depth analysis of the climate finance system as well as other subsystems of climate governance, e.g., systems for governing adaptation or forestry, both of which also overlap with other governance systems, especially development assistance. Further research could also explore how ongoing support from contributor countries and development institutions for fossil fuel production and consumption affects, or is influenced by, fragmentation in climate finance. In addition, research could assess whether the climate finance system has developed-or could develop in future-a reflexive capacity to deliberate on and respond to the degree of fragmentation and complexity in the system (see Dryzek and Pickering 2017).

Since the contributions to this special issue rely mainly on analysis of single cases or small-N studies, broadening the scope through comparative case studies or large-N studies could enhance the generalizability of the findings. Developing the vertical dimension of fragmentation both theoretically and empirically, e.g., through studies of the consequences of fragmentation for climate finance initiatives in developing countries, would also be a fruitful venue for further research.

Research on the climate finance system also needs to take into account ongoing responses to fragmentation, particularly in the light of further developments in global climate policy. The responses proposed by the contributions may be ambitious and challenging to implement, yet there have been some recent signs of progress. At the Paris summit, countries agreed to develop common standards for monitoring climate finance (UNFCCC 2015: Decision 1/CP.21, paragraph 57). Meanwhile, the GCF Board has outlined plans to launch a first replenishment of its resources in 2017 (GCF 2016: 29). Even if these initiatives yield some improvements, much more is needed to ensure that finance is adequate, predictable and equitable. Reaching agreed definitions of contested concepts will also remain challenging, and in the short- to medium-term countries will face trade-offs between improving definitional clarity and muddling through with ambiguous agreements that may nevertheless deliver much-needed assistance in developing countries.

Acknowledgements For insights on the themes of the special issue, we are grateful to the participants in the workshop from which this special issue arose. For comments on drafts of the Editorial, we thank Nina Hall, Pieter Pauw, Harro van Asselt, Romain Weikmans, and Fariborz Zelli. We also thank Joyeeta Gupta for her helpful comments and generous support throughout the review and publication process of this entire special issue. This research was supported under the Australian Research Council's Laureate Fellowship funding scheme (project number FL140100154), and under the project "International Economic Institutions and Domestic Actors in the Climate Regime Complex" funded by the Swedish Research Council [Vetenskapsrådet], the Bank of Sweden Tercentenary Foundation [Riksbankens Jubileumsfond] the Swedish Research Council Formas [Forskningsrådet Formas].

Open Access This article is distributed under the terms of the Creative Commons Attribution 4.0 International License (http://creativecommons.org/licenses/by/4.0/), which permits unrestricted use, distribution, and reproduction in any medium, provided you give appropriate credit to the original author(s) and the source, provide a link to the Creative Commons license, and indicate if changes were made.

\section{References}

Abadie, L. M., Galarraga, I., \& Rubbelke, D. (2013). An analysis of the causes of the mitigation bias in international climate finance. Mitigation and Adaptation Strategies for Global Change, 18(7), 943-955.

Abbott, K. \& Gartner, D. (2011). 2011. The Green Climate Fund and the future of environmental governance. Earth System Governance Working Paper, 16. Lund and Amsterdam: Earth System Governance Project. 
Aglietta, M., Hourcade, J.-C., Jaeger, C., \& Fabert, B. P. (2015). Financing transition in an adverse context: Climate finance beyond carbon finance. International Environmental Agreements: Politics, Law and Economics, 15(4), 403-420.

Ballesteros, A., Nakhooda, S., Werksman, J., \& Hurlburt, K. (2010). Power, responsibility, and accountability: Rethinking the legitimacy of institutions for climate finance. Climate Law, 1, 261-312.

Bernstein, S., \& Cashore, B. (2012). Complex global governance and domestic policies: Four pathways of influence. International Affairs, 88(3), 585-604.

Betzold, C. \& Weiler, F. (2017). Allocation of aid for adaptation to climate change: Do vulnerable countries receive more support? International Environmental Agreements: Politics, Law and Economics. doi:10. 1007/s10784-016-9343-8.

Biermann, F. (2014). Earth system governance: World politics in the anthropocene. Cambridge, MA: MIT Press.

Biermann, F., Pattberg, P., von Asselt, H., \& Zelli, F. (2009). The fragmentation of global governance architectures: A framework for analysis. Global Environmental Politics, 9(4), 14-40.

Buchner, B., Stadelmann, M., Wilkinson, J., Mazza, F., Rosenberg, A., \& Abramskiehn, D. (2014). The global landscape of climate finance 2014. Venice: Climate Policy Initiative.

Ciplet, D., Roberts, J. T., \& Khan, M. (2013). The politics of international climate adaptation funding: Justice and divisions in the greenhouse. Global Environmental Politics, 13(1), 49-68.

Dasgupta, D. \& Climate Finance Unit, Indian Ministry of Finance (2015). Climate change finance, analysis of a recent OECD report: Some credible facts needed. Climate Change Finance Unit, Department of Economic Affairs, Ministry of Finance, Government of India. http://pibphoto.nic.in/documents/rlink/ 2015/nov/p2015112901.pdf. Accessed 24 Apr 2016.

Delina, L. (2017). Multilateral development banking in a fragmented climate finance system: Shifting priorities in energy finance at the Asian Development Bank. International Environmental Agreements: Politics, Law and Economics. doi:10.1007/s10784-016-9344-7.

Dellink, R., den Elzen, M., Aiking, H., Bergsma, E., Berkhout, F., Dekker, T., et al. (2009). Sharing the burden of financing adaptation to climate change. Global Environmental Change, 19, 411-421.

Dryzek, J. S., \& Pickering, J. (2017). Deliberation as a catalyst for reflexive environmental governance. Ecological Economics, 131, 353-360.

Ellis, J., Caruso, R., \& Ockenden, S. (2013). Exploring climate finance effectiveness. OECD/IEA Climate Change Expert Group Papers, No. 2013/04, OECD Publishing, Paris. doi:10.1787/5jzb44nmnbd2-en.

GCF (Green Climate Fund). (2016). Decisions of the Board: Twelfth meeting of the Board, 8-10 March 2016. GCF/B.12/32 (29 March 2016).

Gomez-Echeverri, L. (2013). The changing geopolitics of climate change finance. Climate Policy, 13(5), 32-648.

Grasso, M. (2010). An ethical approach to climate adaptation finance. Global Environmental Change, 20(1), 74-81.

Greene, W. (2004). Aid fragmentation and proliferation: Can donors improve the delivery of climate finance? IDS Bulletin, 35(3), 66-75.

Gupta, S., Harnisch, J., Barua, L., Chingambo, P., Frankel, R. J., Vázquez, G., et al. (2014). Cross-cutting investment and finance issues. In O. Edenhofer, R. Pichs-Madruga, Y. Sokona, E. Farahani, S. Kadner, et al. (Eds.), Climate change 2014: Mitigation of climate change. Contribution of working group III to the fifth assessment report of the intergovernmental Panel on climate change (pp. 1207-1246). Cambridge: Cambridge University Press.

Haites, E. (2011). Climate change finance. Climate Policy, 11(3), 963-969.

Haites, E. (Ed.). (2013). International climate finance. London: Routledge.

Halimanjaya, A. (2015). Climate mitigation finance across developing countries: What are the major determinants? Climate Policy, 15(2), 223-252.

Hall, N. (2017). What is adaptation to climate change? Epistemic ambiguity in the climate finance system. International Environmental Agreements: Politics, Law and Economics. doi:10.1007/s10784-0169345-6.

Hepburn, C., \& Müller, B. (2010). International air travel and greenhouse gas emissions: A proposal for an adaptation levy. World Economy, 33(6), 830-849.

Hoffmann, M. J. (2011). Climate governance at the crossroads: Experimenting with a global response after Kyoto. New York, NY: Oxford University Press.

Hourcade, J., Perrissin Fabert, B., \& Rozenberg, J. (2012). Venturing into uncharted financial waters: An essay on climate-friendly finance. International Environmental Agreements: Politics, Law and Economics, 12(2), 165-186.

Jordan, A., Huitema, D., Hilden, M., van Asselt, H., Rayner, T., Schoenefeld, J., et al. (2015). Emergence of polycentric climate governance and its future prospects. Nature Climate Change, 5(11), 977-982. 
Kaul, I., \& Goulven, K. L. (2003). Financing global public goods: A new frontier of public finance. In I. Kaul, P. Conceicao, K. Le Goulven, \& R. Mendoza (Eds.), Providing global public goods: Managing globalization (pp. 329-370). New York: Oxford University Press.

Keohane, R., \& Levy, M. (Eds.). (1996). Institutions for environmental aid. Pitfalls and promise. Cambridge, MA: The MIT Press.

Keohane, R., \& Victor, D. (2011). The regime complex for climate change. Perspectives on Politics, 9(1), 7-23.

Khan, M. R., \& Roberts, J. T. (2013). Adaptation and international climate policy. Wiley Interdisciplinary Reviews: Climate Change, 4(3), 171-189.

Kim, R. E., \& Mackey, B. (2014). International environmental law as a complex adaptive system. International Environmental Agreements: Politics, Law and Economics, 14(1), 5-24.

King, E. (2015). Top development banks agree definition for climate finance. Climate home, 8 April 2015. http://www.climatechangenews.com/2015/04/08/top-development-banks-agree-definition-for-climatefinance/. Accessed Apr 14, 2016.

Meadows, D. H. (2008). Thinking in systems: A primer. White River Junction: Chelsea Green.

Michaelowa, A. (Ed.). (2012). Carbon markets or climate finance? Low carbon and adaptation investment choices for the developing world. London: Routledge.

Michaelowa, A., \& Michaelowa, K. (2011). Old wine in new bottles? Does climate policy determine bilateral development aid for renewable energy and energy efficiency? International Development Policy, 2, 60-86.

Morin, J., \& Orsini, A. (2013). Regime complexity and policy coherency: Introducing a co-adjustments model. Global Governance, 19(1), 41-51.

Najam, A., Christopoulou, I., \& Moomaw, W. R. (2004). The emergent "system" of global environmental governance. Global Environmental Politics, 4(4), 23-35.

Nakhooda, S. (2015). Climate finance: What was actually agreed in Paris? ODI comment. http://www.odi. org/comment/10201-climate-finance-agreed-paris-cop21. Accessed April 14, 2016.

Nakhooda, S., Fransen, T., Kuramochi, T., Caravani, A., Prizzon, A., Shimizu, N., et al. (2013). Mobilising international climate finance: Lessons from the fast-start finance period. Open Climate Network. http:// www.odi.org.uk/sites/odi.org.uk/files/odi-assets/publications-opinion-files/8686.pdf. Accessed April $14,2016$.

Ostrom, E. (2010). Polycentric systems for coping with collective action and global environmental change. Global Environmental Change, 20(4), 550-557.

Paavola, J., \& Adger, W. N. (2006). Fair adaptation to climate change. Ecological Economics, 56(4), 594-609.

Parker, C., Brown, J., Pickering, J., Roynestad, E., Mardas, N., \& Mitchell, A. W. (2009). The little climate finance book. Oxford: Global Canopy Programme.

Pauw, W. P. (2017). Mobilising private adaptation finance: Developed-country perspectives. International Environmental Agreements: Politics, Law and Economics. doi:10.1007/s10784-016-9342-9.

Pauw, P., Klein, R. J. T., Vellinga, P., \& Biermann, F. (2016). Private finance for adaptation: Do private realities meet public ambitions? Climatic Change, 134(4), 489-503.

Persson, Å., \& Remling, E. (2014). Equity and efficiency in adaptation finance: Initial experiences of the Adaptation Fund. Climate Policy, 14(4), 488-506.

Pickering, J., \& Mitchell, P. (2017). What drives national support for multilateral climate finance? International and domestic influences on Australia's shifting stance. International Environmental Agreements: Politics, Law and Economics. doi:10.1007/s10784-016-9346-5.

Pickering, J., Jotzo, F., \& Wood, P. J. (2015a). Sharing the global climate finance effort fairly with limited coordination. Global Environmental Politics, 15(4), 39-62.

Pickering, J., Skovgaard, J., Kim, S., Roberts, J. T., Rossati, D., Stadelmann, M., et al. (2015b). Acting on climate finance pledges: Inter-agency dynamics and relationships with aid in contributor states. World Development, 68, 149-162.

Pittel, K. \& Rübbelke, D. (2013). International climate finance and its influence on fairness and policy. The World Economy, 36(4), 419-436.

Raustiala, K., \& Victor, D. (2004). The regime complex for plant genetic resources. International Organization, 58(2), 277-310.

Rayner, S. (2010). How to eat an elephant: A bottom-up approach to climate policy. Climate Policy, 10(6), $615-621$.

Roberts, J. T., \& Weikmans, R. (2017). Postface: Fragmentation, failing trust and enduring tensions over what counts as climate finance. International Environmental Agreements: Politics, Law and Economics. doi:10.1007/s10784-016-9347-4. 
Romani, M., \& Stern, N. (2013). Sources of finance for climate action: Principles and options for implementation mechanisms in this decade. In E. Haites (Ed.), International climate finance (pp. 117-134). London: Routledge.

Rübbelke, D. (2011). International support of climate change policies in developing countries: Strategic, moral and fairness aspects. Ecological Economics, 70(8), 1470-1480.

Schalatek, L. (2012). Democratizing climate finance governance and the public funding of climate action. Democratization, 19(5), 951-973.

Skovgaard, J. (2017). Limiting costs or correcting market failures? Finance ministries and frame alignment in UN climate finance negotiations. International Environmental Agreements: Politics, Law and Economics. doi:10.1007/s10784-016-9348-3.

Stadelmann, M., Michaelowa, A., \& Roberts, J. T. (2013). Difficulties in accounting for private finance in international climate policy. Climate Policy, 13(6), 718-737.

Stadelmann, M., Persson, A., Ratajczak-Juszko, I., \& Michaelowa, A. (2014). Equity and cost-effectiveness of multilateral adaptation finance: Are they friends or foes? International Environmental Agreements: Politics, Law and Economics, 14(2), 101-120.

Stadelmann, M., Roberts, J. T., \& Michaelowa, A. (2011). New and additional to what? Assessing options for baselines to assess climate finance pledges. Climate and Development, 3(3), 175-192.

Stewart, R. B., Kingsbury, B., \& Rudyk, B. (Eds.). (2009). Climate finance: Regulatory and funding strategies for climate change and global development. New York and London: New York University Press.

UNEP. (2012). Global environment outlook 5 (GEO 5): Environment for the future we want. Nairobi: United Nations Environment Programme.

UNFCCC. (1992). United Nations Framework Convention on Climate Change. Document FCCC/INFORMAL/84.

UNFCCC. (2001). The Marrakesh Accords. Document FCCC/CP/2001/13/Add.1.

UNFCCC. (2009). Decision 2/CP.15. Copenhagen Accord. Document FCCC/CP/2009/11/Add.1.

UNFCCC. (2010). Decision 1/CP.16. The Cancún Agreements. Document FCCC/CP/2010/7/Add.1.

UNFCCC. (2015). Decision 1/CP.21. Paris Agreement. Document FCCC/CP/2015/L.9/Rev.1.

UNFCCC Standing Committee on Finance. (2014). 2014 Biennial assessment and overview of climate finance flows report. Bonn: UNFCCC.

Van Asselt, H. (2014). The fragmentation of global climate governance: Consequences and management of regime interactions. Cheltenham: Edward Elgar.

Zelli, F. (2011). The fragmentation of the global climate governance architecture. WIRES Climate Change, 2(2), 255-270.

Zelli, F., \& van Asselt, H. (2013). The institutional fragmentation of global environmental governance: Causes, consequences, and responses. Global Environmental Politics, 13(3), 1-13.

Zürn, M., \& Faude, B. (2013). Commentary: On fragmentation, differentiation, and coordination. Global Environmental Politics, 13(3), 119-130. 